\title{
VARIAÇÕES COMPOSICIONAIS DE CROMO-ESPINÉLIOS EM ROCHAS ULTRAMÁFICAS METAMÓRFICAS
}

M.A.F.Candia

O presente trabalho visa investigar as variações composicionais apresentadas por cromo-espinélios de derivação ígnea quando envolvidos em reequilíbrios metamórficos. 0 estudo baseia-se nas variações observadas em cromo-espinélios presentes em rochas ultramáficas dos complexos de Mangabal I e II (Goiás), dois corpos máficos-ultramáficos diferenciados e metamorizados no fácies anfibolito.

Nos complexos investigados, os cromo-espinélios restringem-se às litologias ultramáficas (dunitos, peridotitos e harzburgitos feldspáticos). Amostras com feições reliquiares mostram olivina e cromo-espinélios como fases cumulus, e piroxênios e plagioclásio como fases intercumulus principais. Nestas rochas, cristais idiomórficos, opacos a castanho avermelhados de cromo-espinélio ocorrem tanto inclusos em olivinas, como englobados em fases do material intercumulus, quando então passam a apresentar-se translúcidos, acastanhados.

Os processos metamórficos desenvolveram dois tipos de associações, em função da pressão de água atuante durante os reequilíbrios (CANDIA, 1983 - Tese de doutoramento, Instituto de Geociências, USP). Nos domínios reequilibrados em condições de $\mathrm{P}_{\mathrm{H} 2 \mathrm{O}} \mathrm{P}_{\text {total, observa-se a }}$ desestabilização da associação olivina-ortopiroxênio-hornblenda-espinélio aluminoso, com texturas coronf́ticas ou granoblásticas. O espinélio aluminoso é verde, anedral, contrastando texturalmente e quimicamente do cromo-espinélio.

As rochas reequilibradas em condições de $\mathrm{P}_{\mathrm{H} 2 \mathrm{O}}=\mathrm{P}_{\text {total }}$ desenvolvem a associação olivina-ortopiroxênio-hornblenda-clinocloro.

Os dados de microssonda eletrônica das fases minerais envolvidas neste estudo

Departamento de Mineralogia e Petrologia, Instituto de Geociências, USP. 
mostram que:

a) os cromo-espinélios inclusos em olivinas apresentam-se exsolvidos numa fase mais magnésio-aluminosa e noutra mais rica em $\mathrm{Fe}^{2+} \mathrm{Fe}^{3+}$. O conjunto dos pontos analiticos distribui-se ao longo de uma curva semelhante à curva dos solvus apresentada por EVANS \& FROST (1975, Geoch.Cosmoch.Acta, 39:959-972) para espinélios metamórficos. Os cromo-espinélios inclusos nas fases intercumulus mostram composições mais magnésio-aluminosas e não apresentam exsoluções;

b) as amostras reequilibradas em condições de $\mathrm{P}_{\mathrm{H} 2 \mathrm{O}} \mathrm{P}_{\text {total }}$ mantém as mesmas características acima descritas. Espinélios cromfferos e aluminosos estão ambos presentes, porém em distintos domínios paragenéticos;

c) nas rochas reequilibradas em condições mais hidratadas $\left(\mathrm{P}_{\mathrm{H} 2 \mathrm{O}}=\mathrm{P}_{\text {total }}\right)$ espinélios aluminosos e cromfferos não são mais fases participantes. Observa-se, na associação, a presença de magnetitas com cromo. Tudo indica que o componente magnésio-aluminoso dos espinélios tenha sido assimilado na formação das fases aluminosas da associação (anfibólio e clinocloro), restando o componente rico em $\mathrm{Fe}^{2+} \mathrm{Fe}^{3+}$, representado pelas magnetitas. Desaparecendo a fase originalmente portadora de cromo, este elemento parece se distribuir preferencialmente entre cloritas e magnetitas.

Dentro deste quadro geral, vários pontos especfficos ainda são objeto de detalhamento (partição do cromo nas fases silicatadas e óxidos, superposição de trends ígneos e metamórficos, etc...). Semelhante estudo será estendido a outros corpos ultramáficos metamorfizados, de forma a confrontar o comportamento de cromo-espinélios de outras composições e em diferentes contextos paragenéticos. 